\title{
Expression of endothelial nitric oxide synthase gene in cultured porcine granulosa cells after FSH stimulation
}

\section{K Takesue, M-A Hattori, N Nishida, Y Kato ${ }^{1}$ and $\mathbf{N}$ Fujihara}

Laboratory of Reproductive Physiology, Graduate School of Bioresource and Bioenvironmental Sciences, Kyushu University, Hakozaki, Fukuoka 812-8581, Japan

${ }^{1}$ Biosignal Research Center, Institute for Molecular and Cellular Regulation, Gunma University, Maebashi 371-8512, Japan

(Requests for offprints should be addressed to M-A Hattori; Email: mhattori@agr.kyushu-u.ac.jp)

(Y Kato is now at Laboratory of Molecular Biology and Gene Regulation, Department of Life Science, Faculty of Agriculture, Meiji University)

\begin{abstract}
The present study was designed to investigate nitric oxide (NO) synthesis and the expression of endothelial NO synthase (eNOS) gene in cultured porcine granulosa cells. Granulosa cells prepared from small follicles (1-4 $\mathrm{mm}$ diameter) were cultured in plastic dishes coated with fibronectin in chemically defined medium, and matured after $48 \mathrm{~h}$ of stimulation with FSH. The concentrations of nitrite and nitrate remained relatively constant until $42 \mathrm{~h}$ of stimulation, after which they increased significantly up to twofold at $48 \mathrm{~h}$. NO synthesis was accompanied by an increase in cGMP. Gene expression for eNOS was studied by RT-PCR, and a PCR product of the expected size amplified.
\end{abstract}

eNOS mRNA was expressed in the presence of $\mathrm{FSH}$, but not in the absence of FSH. Although eNOS mRNA was not expressed in the initial period, it was expressed after $12 \mathrm{~h}$ of stimulation with FSH, and remained at a relatively constant level until $48 \mathrm{~h}$. Expression of eNOS mRNA preceded expression of $\mathrm{LH}$ receptor mRNA, which showed a maximal level at $24 \mathrm{~h}$ of stimulation. These observations suggest that eNOS expression is not related to a rapid synthesis of $\mathrm{NO}$ in developing granulosa cells, and that the activation of $\mathrm{NO}$ synthesis is rigidly regulated in the initial period of development.

Fournal of Molecular Endocrinology (2001) 26, 259-265

\section{INTRODUCTION}

Nitric oxide (NO) is a short-lived messenger molecule that mediates a variety of cellular functions. It is generated by three isoforms of $\mathrm{NO}$ synthase (NOS) that are classified into constitutive isoforms such as endothelial (eNOS) and neural NO (nNOS) synthases (Bredt et al. 1991, Lamas et al. 1992) and an inducible isoform (iNOS) (Lowenstein et al. 1992). NO is also synthesized by rat and human ovaries and has been shown to be involved in folliculogenesis, ovulation, apoptotic cell death of follicular cells and steroidogenesis (Ellman et al. 1993, Ben-Shlomo et al. 1994, Chun et al. 1995, Shukovski \& Tsafriri 1995, Hattori et al. 1996, Bonello et al. 1996, Yamauchi et al. 1997). A recent study using rat granulosa cells showed that NO might function as a modulator in cell differentiation, because exposure of the cells to an NO donor caused an increase in the epidermal growth factor receptor contents during cell differentiation (Hattori et al. 1996). In contrast, it has been reported that NO may inhibit steroidogenesis in rat, human and porcine ovarian cells (Adams et al. 1992, Van Voorhis et al. 1994, Olson et al. 1996, Punta et al. 1996).

iNOS is transcriptionally regulated, whereas nNOS and eNOS are considered to be constitutively expressed. However, evidence accumulated in recent years indicates that these two isoforms are also subject to expressional regulation (Weiner et al. 1994, Van Voorhis et al. 1995, Bryant et al. 1995, Arnet et al. 1996, Jablonka-Shariff \& Olson 1997, Vega et al. 1998, El Dwairi et al. 1998, Srivastava et al. 1999, Hangai et al. 1999, Venkov et al. 1999). Changes in their expression may have physiological and pathophysiological consequences. Nitrite, an NO metabolite, is accumulated in luteinized ovarian 
cells of the rat (Olson et al. 1996), suggesting an important function of $\mathrm{NO}$ during the periovulation period. In our previous study (Nishida et al. 2000), we found that NO was synthesized by cultured porcine granulosa cells. Northern blot analysis has shown that iNOS and eNOS are expressed in the rat ovary (Van Voorhis et al. 1995). Expression of iNOS is stimulated by interleukin-1 $\beta$ (IL- $\beta$ ) in cultured rat granulosa cells, but follicle-stimulating hormone $(\mathrm{FSH})$ can not induce iNOS mRNA (Tabraue et al. 1997). However, there is no report concerning expression of the eNOS gene in cultured granulosa cells. To extend understanding of the regulation of eNOS in granulosa cells, it is necessary to investigate the expression of eNOS gene using a cell culture system. In this study, we therefore used RT-PCR analysis to identify eNOS mRNA in cultured porcine granulosa cells, and investigated the expression of eNOS mRNA and NO synthesis during cell maturation.

\section{MATERIALS AND METHODS}

\section{Chemicals}

Ovine FSH (NIDDK-oFSH-20) was supplied by Dr A F Parlow (Harbor-UCLA Medical Center, Torrance, CA, USA). Ham's F-10 and DMEM were obtained from Gibco Laboratories (Grand Island, NY, USA); ISOGEN was from Nippon Gene Co. (Toyama, Japan); the T-primed firststrand kit was from Amersham Pharmacia Biotech (Tokyo, Japan); AmpliTaqGold polymerase was from Perkin-Elmer (Norwalk, CT, USA); the restriction enzyme SmaI was from New England Biolabs (Beverly, MA, USA). All other chemicals used were of reagent grade and obtained from commercial sources.

\section{Cell culture}

Porcine ovaries were obtained at a local slaughterhouse. Granulosa cells were prepared from mediumsized (1-4 $\mathrm{mm}$ diameter) follicles by aspiration with a 20 gauge needle and filtering through a fine stainless mesh. They were treated with $50 \mu \mathrm{g}$ DNase I/ml at $37^{\circ} \mathrm{C}$ for 5 min and washed with Ham's F-10 and DMEM (1:1) supplemented with $10 \mathrm{mM}$ Hepes, $50 \mu \mathrm{g}$ gentamycin $/ \mathrm{ml}$, and $20 \mathrm{IU}$ nystatin $/ \mathrm{ml}$ (Mondschein et al. 1990). Cell viability was determined to be $>95 \%$ by trypan blue exclusion. Cells were seeded at $2 \times 10^{6} /$ dish in a $35 \mathrm{~mm}$ dish coated with human fibronectin (Falcon; Becton-Dickinson, Oxnard, CA, USA) with $100 \mathrm{nM}$ androstenedione, $110 \mathrm{nM}$ hydrocortisone, $1 \mu \mathrm{g}$ insulin $/ \mathrm{ml}, \quad 5 \mu \mathrm{g}$ transferrin $/ \mathrm{ml}$ and $0 \cdot 1 \%(\mathrm{w} / \mathrm{v})$ bovine serum albumin at $39{ }^{\circ} \mathrm{C}$ in a humidified atmosphere of $95 \%$ air and $5 \% \mathrm{CO}_{2}$. FSH was then added to the cultures (culture 0 day), and the cells were cultured for the times indicated.

\section{Nitrite and nitrate assays}

Nitrite and nitrate were separated on a reversephase separation column packed with polystyrene polymer (NO-PASK, $4.5 \times 50 \mathrm{~mm}$ ) with an automated NO detector-HPLC system (ENO-20, EICOM, Kyoto, Japan) as described previously (Hattori et al. 2000a). Nitrate was reduced to nitrite with copper-plated cadmium filings (NO-RED). Nitrite was mixed with a Griess reagent to form a purple azo dye in a reaction coil. The mobile phase was $10 \%$ methanol containing $0 \cdot 15 \mathrm{M} \mathrm{NaCl} / \mathrm{NH}_{4} \mathrm{Cl}$ and $0.5 \mathrm{~g} \mathrm{EDTA}-4 \mathrm{Na} / \mathrm{l}$, applied at a flow rate of $0.33 \mathrm{ml} / \mathrm{min}$. The absorbance of the dye product was measured at $540 \mathrm{~nm}$ by a flow-through spectrophotometer (NOD-10).

\section{cGMP assay}

cGMP was assayed by a specific radioimmunoassay (Hattori et al. 1996) and calculated with the use of a competitive assay computer program. There was $0 \cdot 15 \%$ cross-reactivity between cAMP and the cGMP antiserum. The lower limits of detection for both assays were $0.09 \mathrm{pmol} / \mathrm{ml}$, and the intra-assay and interassay variabilities were $<10 \%$.

\section{RNA isolation}

The total RNAs were extracted from granulosa cells using ISOGEN, according to the instruction manual, and dissolved in $20 \mu \mathrm{l}$ diethylpyrocarbonatetreated water.

\section{RT-PCR}

Single-stranded cDNA was synthesized from these RNA preparations in a reverse transcription (RT) reaction in a final volume of $10 \mu \mathrm{l}$, using a T-primed first-strand kit, according to the instruction manual. The RT reaction was performed at $45^{\circ} \mathrm{C}$ for $1 \mathrm{~h}$ and followed by heating for $5 \mathrm{~min}$ at $70{ }^{\circ} \mathrm{C}$ and then diethylpyrocarbonate-treated water was added (final volume $50 \mu \mathrm{l}$ ). After an initial denaturation step $\left(95^{\circ} \mathrm{C}, 10 \mathrm{~min}\right)$, the $\mathrm{PCR}$ reaction was performed in $10 \mu \mathrm{l}$ of $1 \times$ PCR buffer, 1 or $3 \mu \mathrm{l}$ cDNA, $0 \cdot 2 \mathrm{mM}$ dNTPs, $0 \cdot 25$ U AmpliTaqGold polymerase, and $0 \cdot 2 \mu \mathrm{M}$ each of the synthetic primers. The primer sets were designed from known cDNA sequences of the porcine eNOS (GenBank/Accession NO. U59924) and four porcine luteinizing hormone 
TABLE 1. Oligonucleotide primers used for PCR analysis

\begin{tabular}{|c|c|c|c|}
\hline & Sequences & $\begin{array}{l}\text { Nucleotide } \\
\text { number }\end{array}$ & $\begin{array}{l}\text { Expected PCR } \\
\text { fragment }(\mathrm{bp})\end{array}$ \\
\hline $\begin{array}{l}\text { mRNA } \\
\text { eNOS }\end{array}$ & $\begin{array}{l}\text { Sense: 5'AGCGGCTGCATGACATTGAG3' } \\
\text { Antisense: 5'AAAAGCTCTGGGTGCGTATGCG3' }\end{array}$ & $\begin{array}{l}3092-3111 \\
3547-3526\end{array}$ & 456 \\
\hline LH-R & $\begin{array}{l}\text { Sense: 5'CCAATCTCCTAGATGCCACATTGAC3' } \\
\text { Antisense: 5'GCTCAGCAACAGAAAGAAATCCC3' }\end{array}$ & $\begin{array}{c}861-885 \\
1981-1959\end{array}$ & $\begin{array}{r}1121 \\
855 \\
411 \\
185\end{array}$ \\
\hline GAPDH & $\begin{array}{l}\text { Sense: 5'ACCACAGTCCATGCCATCAC3' } \\
\text { Antisense: 5'TCCACCACCCTGTTGCTGTA3' }\end{array}$ & $\begin{array}{c}861-880 \\
1312-1293\end{array}$ & 452 \\
\hline
\end{tabular}

LH-R, LH receptor.

(LH) receptor isoforms (Loosfelt et al. 1989) (Table 1). LH receptor amplified products were $411 \mathrm{bp}$ and $185 \mathrm{bp}$ (Hattori et al. 2000b). The amplification step consisted of 40 cycles (eNOS) and 34 cycles ( $\mathrm{LH}$ receptor) using denaturation $\left(95^{\circ} \mathrm{C}, 30 \mathrm{~s}\right)$, annealing $\left(54{ }^{\circ} \mathrm{C}, 30 \mathrm{~s}\right)$ and extension reactions $\left(72{ }^{\circ} \mathrm{C}, 2 \mathrm{~min}\right)$ before a final extension step of $10 \mathrm{~min}$ at $72^{\circ} \mathrm{C}$. Glyceraldehyde-3-phosphate dehydrogenase (GAPDH) was used as a control for reaction efficiency and variations in concentrations of mRNA in the original RT reaction. The amplified products were analysed by electrophoresis on $2 \%$ agarose gels, stained with ethidium bromide, and photographed under UV light. The intensities of the bands were quantified as a reference gene of GAPDH using a densitometry program (NIH Image Version 1.58).

The eNOS PCR product was checked by the restriction enzyme, SmaI, and the resulting products were analysed by electrophoresis on $2 \%$ agarose gels.

\section{Statistical analysis}

The data are expressed as means \pm s.E.; differences between them were analysed using Student's $t$-test after analysis of variance.

\section{RESULTS}

\section{cGMP formation and NO synthesis during development}

An increase in cGMP was observed after $48 \mathrm{~h}$ of stimulation with FSH (Fig. 1). Nitrite and nitrate were assayed using an automated NO detectorHPLC system. The concentrations of nitrite and nitrate remained relatively constant until $42 \mathrm{~h}$ of stimulation, after which they increased significantly

www.endocrinology.org up to twofold at $48 \mathrm{~h} \quad(P<0 \cdot 05)$. Production of cGMP stimulated by an $\mathrm{NO}$ donor was observed at the initial periods of the cell development (Nishida et al. 2000). These results indicate that NO synthesis is transiently promoted after $42-48 \mathrm{~h}$ of FSH stimulation, and that NO in turn stimulates guanylate cyclase.

\section{Detection of eNOS mRNA by RT-PCR analysis}

To determine whether eNOS mRNA was present in cultured granulosa cells, we performed RT-PCR on total RNA isolated from the cells. As shown in

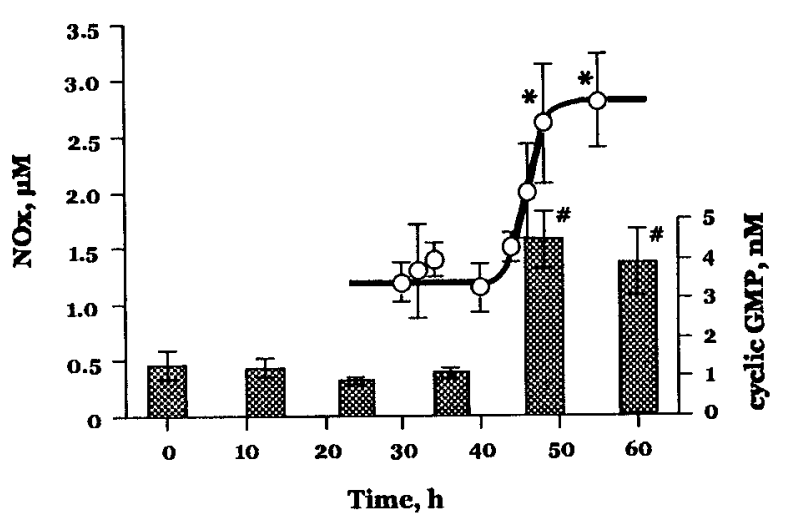

FIGURE 1. Changes in the concentrations of cGMP and NO metabolite (nitrite and nitrate) during maturation of porcine granulosa cells. Granulosa cells were cultured for the indicated times with FSH $(10 \mathrm{ng} / \mathrm{ml})$, and then media were removed for cGMP assay by a specific radioimmunoassay (columns). Nitrite and nitrate $(\bigcirc)$ were assayed using an automated NO detector-HPLC system as described in Materials and Methods. Data are the means \pm s.E. of three independent experiments. NOx, ${ }^{*} P<0 \cdot 05$ compared with 0 h; cGMP, $\# P<0 \cdot 05$ compared with $30 \mathrm{~h}$. 

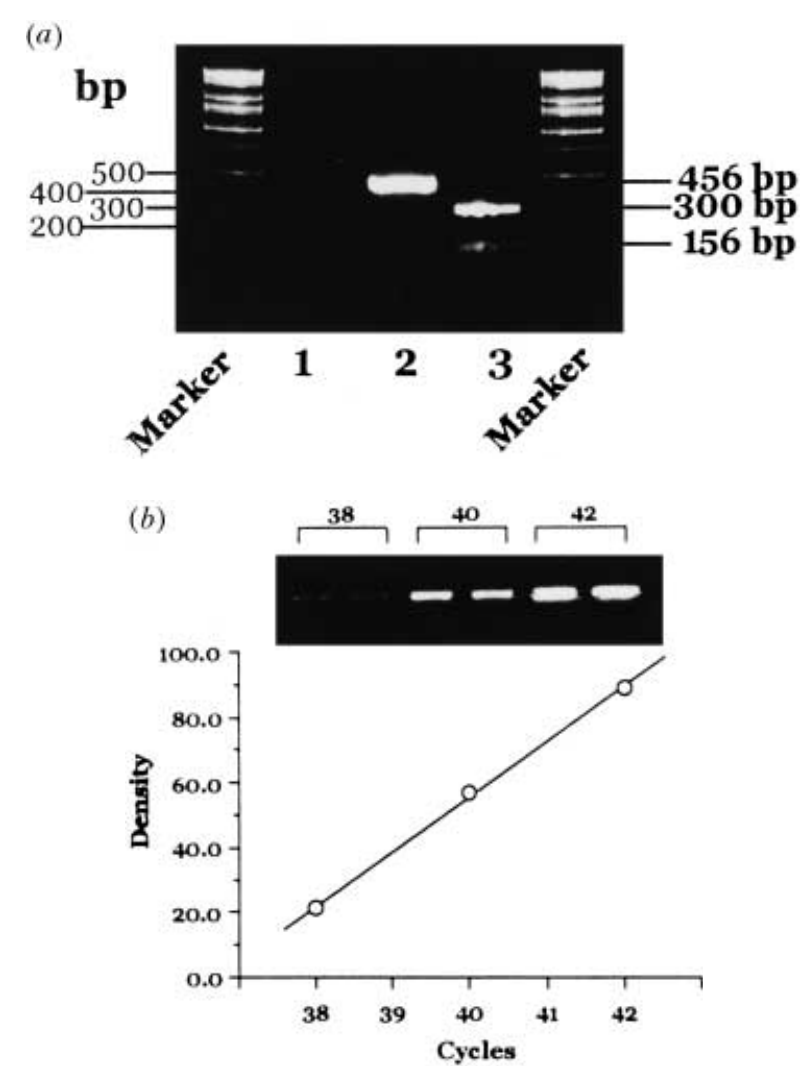

FIGURE 2. Detection of granulosa cell eNOS mRNA by RT-PCR. (a) Cells were incubated for $15 \mathrm{~h}$ and cultured for $48 \mathrm{~h}$ with FSH $(10 \mathrm{ng} / \mathrm{ml})$; thereafter, RNA was isolated and reverse transcribed into cDNA, and samples were subjected to PCR amplification with primers for porcine eNOS cDNA. A 456 bp eNOS PCR product was detected in the RNA samples with RT reaction (lane 2 ), but not without RT reaction (lane 1 ). The PCR fragment was cleaved with SmaI to yield fragments of $300 \mathrm{bp}$ and $156 \mathrm{bp}$ (lane 3). (b) The eNOS cDNA amplified with cycles of PCR increasing from 38 to 42 . Data are the means of duplicate determinations.

Fig. 2a, a PCR product of the expected size (456 bp) amplified using a pair of primers for eNOS (lane 2), but the transcript was not observed without the RT reaction (lane 1). The identity of the PCR product was verified by digesting it with a restriction enzyme. The $456 \mathrm{bp}$ eNOS PCR fragment was cleaved with SmaI, which yielded the expected fragments of $300 \mathrm{bp}$ and $156 \mathrm{bp}$ (Fig. 2a, lane 3). The transcript increased linearly with cycles increasing from 38 to 42 (Fig. 2b). Figure 3 shows a gel electrophoresis of RT-PCR products for eNOS in porcine granulosa cells cultured for $48 \mathrm{~h}$ in the presence or absence of FSH. A transcript with the same size (456 bp) was also detectable in the cells

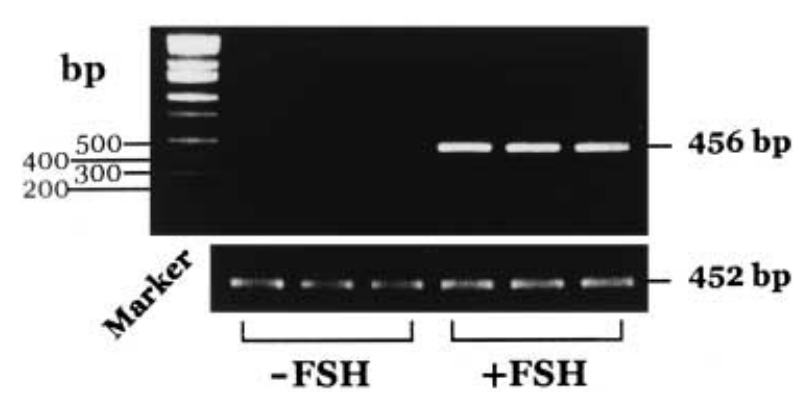

FIGURE 3. RT-PCR analysis of eNOS mRNA expression in granulosa cells cultured with or without FSH. Cells were incubated for $15 \mathrm{~h}$ and cultured for $48 \mathrm{~h}$ in the presence or absence of FSH $(10 \mathrm{ng} / \mathrm{ml})$; thereafter, RNA was isolated and reverse transcribed into cDNA and samples were subjected to PCR amplification with primers for porcine eNOS cDNA. RT-PCR experiments were performed for three different mRNA preparations.

stimulated with FSH, whereas it was not detected in the cells stimulated without FSH.

\section{Time-dependent changes in the levels of granulosa cell eNOS mRNA}

The kinetics of eNOS mRNA expression was examined in granulosa cells stimulated with FSH by using RT-PCR analysis, and compared with changes in $\mathrm{LH}$ receptor $\mathrm{mRNA}$ expression. After stimulation with FSH for the times indicated, cDNA was prepared from total RNA isolated. Figure 4 shows a gel electrophoresis of RT-PCR products for eNOS and LH receptor. The transcript of eNOS was detected after $12 \mathrm{~h}$ of FSH stimulation, and remained constant until $48 \mathrm{~h}$ (Fig. 4a and c). In contrast, $\mathrm{LH}$ receptor mRNA reached a maximal level at $24 \mathrm{~h}$ of stimulation, and decreased progressively to $48 \mathrm{~h}$ (Fig. $4 \mathrm{~b}$ and c).

\section{DISCUSSION}

It has been demonstrated using immunocytochemical staining and Northern blot analysis that eNOS and iNOS are expressed in the rat ovary (Van Voorhis et al. 1995, Jablonka-Shariff \& Olson 1997). In the present study using RT-PCR analysis, expression of eNOS mRNA was also detected in cultured porcine granulosa cells. Van Voorhis et al. (1995) reported that eNOS mRNA levels increased after stimulation with gonadotrophin and peaked in ovaries containing ovulatory follicles, before declining in the luteal phase. Jablonka-Shariff \& Olson (1997) reporterd that the levels of immunostaining 


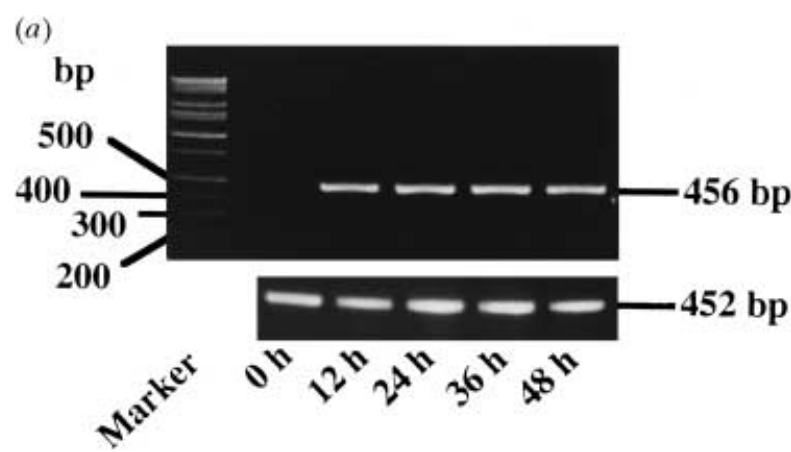

trophin. In contrast, a slight increase in iNOS was observed in the theca cell layer and stroma during the hormonal stimulation. These reports indicate that expression of granulosa cell eNOS is dependent upon gonadotrophin stimulation. However, no reports have described expression of eNOS mRNA during in vitro development of granulosa cells. In the present study, eNOS mRNA was expressed after $12 \mathrm{~h}$ of $\mathrm{FSH}$ stimulation, then the mRNA levels remained relatively constant until $48 \mathrm{~h}$ of stimulation. A maximal expression of LH receptor mRNA was detected after $24 \mathrm{~h}$ of stimulation. A similar finding for $\mathrm{LH}$ receptor mRNA expression was also reported using Northern blots and receptor binding studies (Goxe et al. 1992). As NO may be involved in ovulation (Shukovski \& Tsafriri 1995, Bonello et al. 1996, Yamauchi et al. 1997) and differentiation of the granulosa cells (Hattori et al. 1996, Nishida et al. 2000), it is reasonable to propose that expression of eNOS mRNA preceded maximal expression of $\mathrm{LH}$ receptor mRNA in cultured granulosa cells. eNOS has been considered to be a constitutively expressed protein, but there are many reports of regulation of the expression of its gene (Weiner et al. 1994, Bryant et al. 1995, Van Voorhis et al. 1995, Arnet et al. 1996, JablonkaShariff \& Olson 1997, El Dwairi et al. 1998, Vega et al. 1998, Hangai et al. 1999, Srivastava et al. 1999, Venkov et al. 1999). In post-ischaemic rat retina, eNOS mRNA increased to a peak at $12 \mathrm{~h}$, and decreased progressively beyond $24 \mathrm{~h}$ (Hangai et al. 1999). Expression of eNOS mRNA increases within $3 \mathrm{~h}$ in bovine aortic endothelial cells exposed to ethanol (Venkov et al. 1999). Mechanical forces seem to induce expression of eNOS gene in these cells, and the expression is relatively quick. However, it is also known that expression of eNOS is regulated by hormonal stimulation (Weiner et al. 1994, Bryant et al. 1995, Van Voorhis et al. 1995, Jablonka-Shariff \& Olson 1997). In human corpus luteum, expression of eNOS is detected in high levels in mid and early corpus luteum, and decreased in late corpus luteum (Vega et al. 1998). In the development of rat skeletal muscle, the level of eNOS mRNA increases during the late gestational and early postnatal periods (El Dwairi et al. 1998).

Expression of eNOS was continuously observed after $12 \mathrm{~h}$ of FSH stimulation, but NO synthesis did not occur until approximately $42 \mathrm{~h}$. A maximal synthesis of $\mathrm{NO}$ was observed after approximately $48 \mathrm{~h}$ of $\mathrm{FSH}$ stimulation, and the synthesis was accompanied by a transient increase in cGMP. These findings indicate that NOS expression is not necessarily related to a rapid synthesis of NO and that the activation of $\mathrm{NO}$ synthesis may be rigidly cell laver during follicle growth of rat ovaries that was induced by pregnant mare's serum gonado- 
regulated in the granulosa cells. It seems that $\mathrm{NO}$ is not required at least for the initial stage of granulosa cell development. Although it is not known what stimulus activates eNOS in granulosa cells, eNOS requires $\mathrm{Ca}^{2+}$ and calmodulin for its activity. Several signalling pathways may be involved in the synthesis of NO, depending on the cell type. The $\mathrm{Ca}^{2+} /$ calmodulin system and tyrosine kinasedependent pathway were reported to be involved in the activation of eNOS (Tsukahara et al. 1994a,b). Gonadotrophin may regulate the expression of eNOS and iNOS during ovarian follicular development and luteinization (Van Voorhis et al. 1995, Jablonka-Shariff \& Olson 1997), but there has been no report of the regulation of NOS activation.

It has been reported that iNOS mRNA is not detectable in rat ovaries containing ovulatory follicles after injection of gonadotrophin (Van Voorhis et al. 1995); however, iNOS mRNA was not determined in the present study. In cultured rat granulosa cells, IL- $\beta$ induces activation of iNOS, but FSH can not induce iNOS mRNA (Tabraue et al. 1997). In addition, it has been reported that iNOS is expressed in the theca cell layer and stroma surrounding immature follicles in rat ovaries (Jablonka-Shariff \& Olson 1997). As iNOS inducers such as IL- $\beta$ were not contained in our culture system, NO released from porcine granulosa cells might result from activation of eNOS. The mRNA levels for these isoenzymes are differentially regulated, and eNOS, but not iNOS, seems to be necessary for the process of maturation of granulosa cells. The characteristics of eNOS - that is, it is a constitutively expressed gene producing small amounts of synthesized $\mathrm{NO}$ - may be significant for the function of granulosa cells.

In conclusion, the present study using RT-PCR demonstrated that eNOS mRNA was expressed before that of $\mathrm{LH}$ receptor mRNA in FSHstimulated granulosa cells, but that $\mathrm{NO}$ synthesis occurred in the terminal stages of cell maturation.

\section{ACKNOWLEDGEMENTS}

We are grateful to Dr A F Parlow for the supply of ovine FSH. This study was supported by a Grant-in-Aid for Scientific Research (B) No. 09460139 from the Japanese Ministry of Education, Science and Culture (to M-A H).

\section{REFERENCES}

Adams ML, Mock B, Truong R \& Cicero TJ 1992 Nitric oxide control of steroidogenesis: endocrine effects of
$N^{\mathrm{G}}$-nitro-L-arginine and comparisons to alcohol. Life Sciences $\mathbf{5 0}$ 35-40.

Arnet UA, McMillan A, Dinerman JL, Ballermann B \& Lowenstein CJ 1996 Regulation of endothelial nitric-oxide synthase during hypoxia. Fournal of Biological Chemistry 271 15060-15073.

Ben-Shlomo I, Kokia E, Jackson MJ, Adashi EY \& Payne DW 1994 Interleukin-1 $\beta$ stimulates nitrite production in the rat ovary: evidence for heterologous cell-cell interaction and for insulin-mediated regulation of the inducible isoform of nitric oxide synthase. Biology of Reproduction 51 310-318.

Bonello N, Mckie K, Jasper M, Andrew L, Ross N, Braybon E, Brannstrom M \& Norman RJ 1996 Inhibition of nitric oxide: effects on interleukin-1 $\beta$-enhanced ovulation rate, steroid hormone, and ovarian leukocyte distribution at ovulation in the rat. Biology of Reproduction 54 436-445.

Bredt DS, Hwang PM, Glatt CE, Lowenstein C, Reed RR \& Snyder SH 1991 Cloned and expressed nitric oxide synthase structurally resembles cytochrome P-450 reductase. Nature $351714-718$.

Bryant CE, Tomlinson A, Mitchell JA, Thiemermann C \& Willoughby DA 1995 Nitric oxide synthase in the rat fallopian tube is regulated during the oestrous cycle. Fournal of Endocrinology 146 149-157.

Chun S-Y, Eisenhauer KM, Kubo M \& Hsueh AJW 1995 Interleukin-1 $\beta$ suppresses apoptosis in rat ovarian follicles by increasing nitric oxide production. Endocrinology 136 3120-3127.

El Dwairi Q, Guo Y, Comtois A, Zhu E, Greenwood MT, Bredt DS \& Hussain SN 1998 Ontogenesis of nitric oxide synthases in the ventilatory muscles. American fournal of Respiratory Cell and Molecular Biology 18 844-852.

Ellman C, Corbett JA, Misko TP, McDaniel M \& Beckerman KP 1993 Nitric oxide mediates interleukin-1-induced cellular cytotoxicity in the rat ovary: a potential role for nitric oxide in the ovulatory process. Fournal of Clinical Investigation 92 3053-3056.

Goxe B, Salesse R, Remy JJ, Genty N \& Garnier J 1992 LH receptor RNA and protein levels after hormonal treatment of porcine granulosa cells in primary culture. Fournal of Molecular Endocrinology 8 119-129.

Hangai M, Miyamoto K, Hiroi K, Tujikawa A, Ogura Y, Honda Y \& Yoshimura N 1999 Roles of constitutive nitric oxide synthase in postischemic rat retina. Investigative Ophthalmology and Visual Science 40 450-458.

Hattori M-A, Sakamoto K, Fujihara N \& Kojima I 1996 Nitric oxide: a modulator for the epidermal growth factor receptor expression in developing ovarian granulosa cells. American Fournal of Physiology 270 C812-C818.

Hattori M-A, Nishida N, Takesue K, Kato Y \& Fujihara N $2000 a$ FSH suppression of nitric oxide synthesis in porcine oocytes. Fournal of Molecular Endocrinology 24 65-73.

Hattori M-A, Takesue K, Nishida N, Kato Y \& Fujihara N $2000 b$ Inhibitory effect of retinoic acid on the development of immature porcine granulosa cells to mature cells. Fournal of Molecular Endocrinology 25 53-61.

Jablonka-Shariff A \& Olson LM 1997 Hormonal regulation of nitric oxide synthases and their cell-specific expression during follicular development in the rat ovary. Endocrinology 138 460-468.

Lamas S, Marsden PA, Li GK, Tempst P \& Michel T 1992 Endothelial nitric oxide synthase: molecular cloning and characterization of a distinct constitutive enzyme isoform. PNAS $896348-6352$.

Loosfelt H, Misrahi M, Atger M, Salesse R, Vu Hai-Luu Thi MT, Jolivet A, Guiochon-Mantel A, Sar S, Jallal B, Garnier J \& Milgrom E 1989 Cloning and sequencing of 
porcine $\mathrm{LH}-\mathrm{hCG}$ receptor cDNA: variants lacking transmembrane domain. Science 245 525-528.

Lowenstein CJ, Glatt CS, Bredt DS \& Snyder SH 1992 Cloned and expressed macrophage nitric oxide synthase contrasts with the brain enzyme. PNAS 89 6711-6715.

Mondschein JS, Smith SA \& Hammond JM 1990 Production of insulin-like growth factor binding proteins (IGFBPs) by porcine granulosa cells: identification of IGFBP-2 and -3 and regulation by hormones and growth factors. Endocrinology 127 2298-2306.

Nishida N, Takesue K, Hattori M-A, Kato Y, Wakabayashi K \& Fujihara N 2000 Modulatory action of nitric oxide on the expression of transcription factor genes, c-fos and c-jun, in developing porcine granulosa cells in vitro. Fournal of Reproduction and Development 46 167-175.

Olson LM, Jones-Burton CM \& Jablonka-Shariff A 1996 Nitric oxide decreases estradiol synthesis of rat luteinized ovarian cells: possible role for nitric oxide in functional luteal regression. Endocrinology 137 3531-3539.

Punta KD, Charreau EH \& Pignataro OP 1996 Nitric oxide inhibits Leydig cell steroidogenesis. Endocrinology 137 5337-5343.

Shukovski L \& Tsafriri T 1995 The involvement of nitric oxide in the ovulatory process in the rat. Endocrinology 135 2287-2290.

Srivastava VK, Hiney JK, Rettori V \& Dees WL 1999 Effects of ethanol on intraovarian nitric oxide production in the prepubertal rat. Fournal of Endocrinology 161 69-75.

Tabraue C, Penate RD, Gallardo G, Hernandez I, Quintana J, Blanco FL, Reyes JG, Fanjul LF \& Galarreta CMR 1997 Induction of guanosine triphosphate-cyclohydrolase by follicle-stimulating hormone enhances interleukin-1 $\beta$ stimulated nitric oxide synthase activity in granulosa cells. Endocrinology 138 162-168.
Tsukahara H, Ende H, Magazine HI, Bahou WF \& Goligorsky MS $1994 a$ Molecular and functional characterization of the non-isopeptide-selective $\mathrm{ET}_{\mathrm{B}}$ receptor in endothelial cells: receptor coupling to nitric oxide synthase. Fournal of Biological Chemistry $26921778-21785$.

Tsukahara H, Gordienko DV, Tonshoff B, Gelate MC \& Goligorsky MS $1994 b$ Direct demonstration of insulin-like growth factor-I-induced nitric oxide production by endothelial cells. Kidney International 45 598-604.

Van Voorhis BJ, Dunn MS, Snyder GD \& Weiner CP 1994 Nitric oxide: an autocrine regulator of human granulosa-luteal cell steroidogenesis. Endocrinology 135 1799-1806.

Van Voorhis BJ, Moore K, Strijbos PJL, Nelson S, Baylis SA, Grzybicki D \& Weiner CP 1995 Expression and localization of inducible and endothelial nitric oxide synthase in the rat ovary. Fournal of Clinical Investigation 96 2719-2726.

Vega M, Johnson MC, Diaz HA, Urrutia LR, Troncoso JL \& Devoto L 1998 Regulation of human luteal steroidogenesis in vitro by nitric oxide. Endocrine 8 185-191.

Venkov CD, Myers PR, Tanner MA, Su M \& Vaughan DE 1999 Ethanol increases endothelial nitric oxide production through modulation of nitric oxide synthase expression. Thrombosis and Haemostasis 81 638-642.

Weiner CP, Lizasoain I, Baylis SA, Knowles RG, Charles IG \& Moncada S 1994 Induction of calcium-dependent nitric oxide synthases by sex hormones. PNAS 91 5212-5216.

Yamauchi J, Miyazaki T, Iwasaki S, Kishi I, Kuroshima M, Tei C \& Yoshimura Y 1997 Effects of nitric oxide on ovulation and ovarian steroidogenesis and prostaglandin production in the rabbit. Endocrinology 138 3630-3637.

RECEIVED 18 September 2000

ACCEPTED 21 December 2000 